Dudi Badruzaman / Ta'dib: Jurnal Pendidikan Islam, Vol. 8 No. 1 (2019) 591-600

ISSN 1411-8173 | E-ISSN 2528-5092

https://ejournal.unisba.ac.id/index.php/tadib/article/view/5063

\title{
HUBUNGAN ANTARA PERHATIAN ORANG TUA TERHADAP PRESTASI BELAJAR SISWA PADA MATA PELAJARAN PENDIDIKAN AGAMA ISLAM
}

\author{
Dudi Badruzaman \\ Sekolah Tinggi Agama Islam Sabili Bandung \\ Jln. Gagak No. 15, Sadang Serang, Kecamatan Coblong, \\ Kota Bandung Jawa Barat 40133 \\ Email: badruzaman.dudi@yahoo.com \\ DOI: $10.29313 /$ tjpi.v8i1.5063
}

Accepted: September 9th, 2018. Approved: October 10th, 2019. Published: October 14th, 2019

\begin{abstract}
This study aims to determine the relationship of parents' attention to student achievement in Islamic Religious Education subjects at SMK Negeri 1 Rajadesa Ciamis Regency, the research method used is the descriptive correlational method. While the data collection techniques used are observation, questionnaires, and documentation. The results of the research The results of research that have been conducted with the number of respondents in descriptive statistics, normality test variable data, the results of the correlation coefficient test influence of variable X (parent's attention on Islamic religious education subjects in SMK Negeri 1 Rajadesa, Rajadesa District, Ciamis Regency) on the variable Y (student learning achievements in Islamic education subjects at SMKNegeri 1 Rajadesa, Rajadesa District, Ciamis Regency) is a very weake correlation, meaning that parents who are very busy with their work so that the lack of attention to children bas a negative impact on student achievement, compared to their students parents who pay full attention to their children and have good achievements.
\end{abstract}

Keywords: Attention of Parents; Student achievement.

\begin{abstract}
Abstrak
Penelitian ini bertujuan untuk mengetahui hubungan perbatian orang tua terhadap prestasi belajar siswa pada mata pelajaran Pendidikan Agama Islam di SMK Negeri 1 Rajadesa Kabupaten Ciamis. Metode penelitian yang digunakan adalah metode deskriptif korelasional, Sedangkan teknik pengumpulan data yang digunakan adalah observasi, angket, dan dokumentasi. Hasil penelitian dari Hasil penelitian yang telah dilakukan dengan jumlah responden dalam deskriptif statistik, uji normalitas data variabel, hasil dari uji koefisien korelasi pengarub variabel X (perbatian orangtua pada mata pelajaran pendidikan agama Islam di SMK Negeri 1 Rajadesa Kecamatan Rajadesa Kabupaten Ciamis) terbadap variabel Y (prestasi belajar siswa pada mata pelajaran pendidikan agama Islam di SMK Negeri 1 Rajadesa Kecamatan Rajadesa Kabupaten Ciamis) merupakan korelasi sangat lemah, artinya babwa orang tua yang sangat sibuk dengan pekerjaannya sehingga kurang perhatian terbadap anak berdampak buruk terhadap prestasi belajar siswa, dibandingan dengan mereka para orang tua yang memberikan perhatian penuh terhadap anaknya dan memiliki prestasi yang baik.
\end{abstract}

Kata Kunci: Perhatian Orang Tua; Prestasi Belajar Siswa. 


\section{PENDAHULUAN}

Dalam ranah biologi penciptaan manusia melalui berbagai tahap dan proses yang terjadi di dalam rahim wanita. Ternyata Al-Quran juga sudah menjelaskan tentang proses pembentukan manusia dimulai dari janin hingga menjadi bayi dengan bentuk yang lengkap. Penjelasan tersebut tertera pada surat (al-Mu'minun 12-14), Kehidupan manusia dimulai saat sel sperma dari calon ayah dan sel telur calon ibu yang bertemu di tubuh si calon ibu, menyatu dan terus bertumbuh serta berkembang dari satu sel menjadi berjuta-juta sel membentuk tubuh manusia lengkap dengan organ-organnya dan kemudian lahir menjadi bayi. ${ }^{1}$

Sejak bayi dilahirkan pertama kali ke dunia, telah dilakukan usaha-usaha pendidikan. Orangtua telah berusaha mendidik anak-anaknya, walaupun dengan cara yang sangat sederhana. Berawal dari manusia yang lemah tidak bisa memindahkan tubuhnya tanpa dibantu seorang ibu, kemudian berkembang motoriknya sedikit demi sedikit, sehingga menjadi manusia yang dapat memindahkan diri sampai dapat berjalan dari satu tempat ke tempat lain.

Bayi yang terus berkembang kemudian menunjukkan perubahan dalam kemampuan kognitif dan reaksi terhadap stimulus lingkungan. Masalah pendidikan adalah masalahnya setiap orang dari dulu hingga sekarang dan di waktu-waktu yang akan datang. Pendidikan merupakan suatu keharusan bagi setiap pendidik yang bertanggungjawab bahwa dalam melaksanakan tugasnya harus berbuat yang sesuai dengan keadaan anak didik. ${ }^{2}$

Pendidikan setiap manusia yang berawal dari orangtuanya dalam konteks sekarang sangat relevan untuk mengatasi prestasi belajar setiap manusia di lembaga pendidikan. Hal ini berkaitan dengan firman Allah swt dalam QS Luqman: 17 sebagai

\footnotetext{
${ }^{1}$ Sumanto. Psikologi Perkembanga Fungsi dan Teori. (Jakarta: PT Buku Seru 2014), hlm.1

2 Suryabrata, Sumadi.Psikologi Pendidikan. Jakarta: PT
}

berikut: "Hai anakku, dirikanlah shalat dan surublah (manusia) mengerjakan yang baik dan cegablah (mereka) dari perbuatan yang mungkar dan bersabarlah terhadap apa yang menimpa kamu. Sesunggubnya yang demikian itu termasuk hal-hal yang diwajibkean (oleh Allab)" (QS Luqman: 17).

Dari ayat di atas dapat dipahami bahwa peran ayah dan ibu sangatlah penting dalam perjalanan hidup anak-anaknya, khususnya dalam hal pendidikan. Ayah dan ibu yang baik adalah mereka yang memberikan bimbingan serta arahan kepada anak-anaknya, sesuai dengan yang dijelaskan dalam QS Luqman [31]: 17 yaitu shalat, mencegah kemungkaran, malakukan kebaikan serta bersabar atas segala sesuatu yang menimpa pada diri setiap manusia, karena itu semua merupakan kewajiban dari Allah swt. Salah satu cara untuk mencegah kemungkaran dan melakukan kebaikan yang diperintahkan oleh Allah swt yaitu dengan menuntut ilmu (belajar).

Dengan belajar, seseorang dapat mengetahui perbedaan antara perbuatan yang baik dan perbuatan yang tidak baik (munkar), sehingga ia akan mampu mencegah hal-hal yang mungkar dengan cara melakukan hal-hal kebaikan. Selain itu, karena belajar pula seseorang akan meraih prestasi dan cita-cita yang diharapkannya.

Anak-anak dapat berprestasi sangat baik, baik, cukup, atau bahkan kurang baik atau kurang dari kata cukup, salah satunya adalah karena mereka semua mendapatkan perhatian yang sesuai dari orangtuanya. Tidak sedikit orangtua yang mempunyai berbagai kesibukan pada zaman sekarang. Tetapi, seberapa banyak kesibukan orangtua, maka mereka harus tetap memperhatikan aktivitas anak- anaknya, khususnya dalam prestasi belajarnya di setiap lembaga pendidikan.

Dalam salah satu keluarga saya mendapati seorang anak tetangga di desa tanjungsari Rt 05 Rw 04 (Anisa, 13 tahun) pernah ada kejadian akibat dari kesibukan

Raja Grafindo Persada 1984). hlm.1 
orangtuanya yang menjadi pegawai di perkantoran, maka anak-anak mereka menjadi kurang perhatian, kurang kasih sayang, dan kurang bimbingan dalam pendidikannya, bahkan mereka menjadi anak- anak yang terkenal nakal dan mendapatkan peringkat pertama dari urutan terakhir di sekolahnya. Dalam kasus keluarga lain juga terdapat anak yang kurang perhatian dari orangtuanya, padahal ia memiliki tingkat kecerdasan yang baik, namun karena kurang bimbingan dan kurang ketekunan dalam membimbing proses belajar dari orangtuanya di rumah, maka ia tidak bisa memperoleh prestasi belajar yang baik.

Perhatian orangtua terdiri dari berbagai macam, baik dari segi fisik maupun segi psikisnya. Sebagian orangtua lebih memperhatikan kebutuhan anak-anaknya dalam segi fisik dibandingkan segi psikisnya, sehingga orangtua cukup memberikan perhatian dengan cara menyediakan fasilitas serta uang yang berlebihan kepada anakanaknya untuk kepentingan pembelajaran tanpa memperhatikan segi psikisnya. Orangtua tersebut selalu memberikan apapun yang anak-anaknya inginkan setiap kali anak-anaknya minta, sehingga anakanaknya menjadi tidak dewasa, menganggap semuanya mudah untuk dilakukan, dan tidak memperhatikan prestasi belajarnya. Orangtua yang seperti itu juga biasanya terlalu sibuk dengan pekerjaannya, sehingga tidak memiliki waktu untuk berkumpul bersama keluarganya, khususnya dengan anak-anaknya, apalagi sampai membimbing anak-anaknya dalam belajar. Sebagian orangtua yang lain lebih memperhatikan kebutuhan anak-anaknya dalam segi psikis serta memberikan fasilitas dan uang yang secukupnya terhadap anak-anak mereka dalam proses pembelajaran, sehingga anak tersebut menjadi lebih dewasa, menghargai orangtua dan proses pendidikannya. ${ }^{3}$

Kata perhatian terkadang dianggap sebagai hal yang sepele oleh sebagian orang,

3 Gunarsa, Ny Singgih. Psikologi untuk Keluarga. (Jakarta: Gunung Mulia 2014) hal, 53.

${ }^{4}$ Wawancara terhadap ibu Wida, sebagai satu wali namun pada kenyataannya bentuk perhatian sangatlah berpengaruh terhadap kehidupan seseorang, khususnya perhatian orangtua terhadap anak-anaknya dalam prestasi belajar di lembaga pendidikan. Memang tidak semua orang yang berprestasi baik itu dipengaruhi oleh perhatian orangtuanya, tetapi masih banyak siswa di SMK Negeri 1 Rajadesa yang mendapatkan prestasi belajar kurang dari kriteria ketuntasan minimal (KKM) karena kurangnya atau bahkan tidak adanya perhatian dari orangtua mereka masingmasing. Hal ini membuktikan bahwa perhatian orangtua saling berkaitan dengan prestasi belajar siswa di SMK Negeri 1 Rajadesa. ${ }^{4}$

Kegagalan siswa SMK Negeri 1 Rajadesa salah satunya dipengaruhi oleh perhatian orangtuanya. Sebagian besar orangtua siswa SMK Negeri 1 Rajadesa bekerja sebagai petani, karyawan di pabrik, di luar kota, dan di tempat lainnya. Semua jenis pekerjaan itu tentunya menjadi suatu penyebab kurangnya intensitas orangtua dalam memperhatikan anak-anaknya, khusunya dalam belajar.

Orangtua siswa SMK Negeri 1 Rajadesa setiap harinya berangkat bekerja di pagi hari dan pulang bekerja di sore hari, sehingga ketika pagi hari sebelum mereka berangkat terkadang anak-anaknya belum bangun tidur dan ketika sore hari terkadang orangtua dan anak-anaknya tidak menyempatkan diri untuk mengobrol karena kecapean langsung istirahat di kamarnya masing-masing. Orangtua yang bekerja di luar kota terkadang jarang pulang, sehingga waktu untuk bertemu dengan keluarganya sangat sedikit. Keadaan orangtua yang seperti ini terkadang menjadikan anakanaknya menjadi acuh terhadap prestasi belajarnya.

Sekitar $65 \%$ anak-anak yang memilih makan di luar rumah, sekedar menonton televisi di rumah tetangga, belajar di rumah temannya, dan melakukan aktivitas

kelas di smk negeri rajadesa kabupaten ciamis (kamis, 21 juli 2019) 
lainnya di luar rumah karena di rumahnya sendiri tidak ada temannya. Pertemuan orangtua yang bekerja di luar kota dan SMK Negeri 1 Rajadesa terkadang bisa terjadi selama tiga bulan satu kali, satu tahun sekali, atau bahkan ada yang sampai dua dan tiga tahun sekali. Dari perlakuan orangtuanya yang sibuk dengan pekerjaan dan tidak perhatian tersebut menjadikan anak-anaknya tidak terlalu mementingkan prestasi belajar yang maksimal, karena orangtua hanya memberikan perhatian atau dukungan secara materi atau fisiknya saja, tanpa memberikan motivasi lainnya yang berhubungan dengan prestasi belajarnya. $^{5}$

Sehubungan dengan hal di atas, maka setiap manusia sangatlah membutuhkan perhatian dari ayah dan ibu mereka dalam segala bentuk kehidupan, terutama dalam prestasi belajarnya. Perhatian orangtua menjadi faktor intern yang sangat mendukung terhadap prestasi belajar, sehingga penulis dalam penelitian ini mengambil judul "Hubungan antara perhatian orangtua dan prestasi belajar siswa pada mata pelajaran pendidikan agama Islam (penelitian di SMK Negeri 1 Rajadesa Kabupaten Ciamis)" karena sangat penting guna memberikan pemahaman tentang pendidikan dan prestasi yang diharapkan dari proses pendidikan di setiap lembaga pendidikan, maksud indikator untuk orang tua yang di pakai oleh peneliti disini adalah ayah dan ibu siswa SMK Negeri 1 Rajadesa Kabupaten Ciamis.

Kata perhatian tidaklah selalu digunakan dalam arti yang sama. Menurut Suryabrata definisi perhatian adalah sebagai berikut: ${ }^{6}$

1. Perhatian adalah pemusatan tenaga psikis tertuju pada suatu objek dan

2. Perhatian adalah banyak sedikitnya kesadaran yang menyertai sesuatu

\footnotetext{
5 Observasi kepada salah satu siswa berama Devi siswa smk negeri rajadesa kabupaten ciamis (kamis, 21 juli 2019)

6 Suryabrata, Sumadi.Psikologi Pendidikan. (Jakarta:

PT Raja Grafindo Persada 1984). hlm.14

${ }^{7}$ Kartono, Kartini. Peranan Keluarga Memandu Anak,
}

aktivitas yang dilakukan.

Kedua definisi di atas dapat digunakan sesuai dengan konteksnya atau kalimatnya serta sesuai dengan situasi dan kondisinya. Perhatian erat kaitannya dengan kesadaran jiwa terhadap sesuatu objek yang direaksi pada sesuatu waktu. Terang tidaknya kesadaran seseorang terhadap suatu objek tertentu tidak tetap, ada kalanya kesadaran seseorang meningkat (menjadi terang) dan ada kalanya menjadi menurun (samarsamar).

Taraf kesadaran seseorang akan meningkat apabila jiwa orang tersebut dalam mereaksi sesuatu meningkat juga. Apabila taraf kekuatan kesadaran seseorang menjadi naik atau giat karena suatu sebab, maka orang tersebut berada pada permulaan perhatian. Perhatian timbul dengan adanya pemusatan kesadaran seseorang terhadap sesuatu. $^{7}$

Berdasarkan beberapa pengertian perhatian di atas, maka dapat disimpulkan bahwa perhatian merupakan suatu kesadaran jiwa seseorang yang ditujukan kepada suatu objek atau kumpulan objek tertentu yang berada dalam diri maupun luar diri.

\section{METODE PENELITIAN}

Metode yang digunakan dalam penelitian ini adalah metode penelitian deskriptif korelasional dengan pendekatan kuantitatif. Menurut Sugiyono menyatakan bahwa:

Metode penelitian deskriptif adalah metode yang digunakan untuk menganalisis data dengan cara mendeskripsikan atau menggambarkan data yang telah terkumpul sebagaimana adanya tanpa bermaksud membuat kesimpulan yang berlaku umum atau digeneralisasikan. ${ }^{8}$

Sari Psikologi Terapan. (Jakarta: Rajawali Press 1982) hlm. 48

8 Sugiyono. Metode Penelitian Kuantitatif Kualitatif \& RND. Bandung: Alfabeta, 2013),hlm, 147. 


\section{Teknik Analisis Data}

1. Analisis Regresi Linear Sederhana

Analisis regresi sederhana dapat dimanfaatkan untuk mengetahui bagaimana variabel dependen (kriteria dapat diprediksikan melalui variabel independen/predikator

Adapun persamaan regresi adalah berikut:

$$
Y=a+b X
$$

(Sugiyono, 2015: 188)

Dimana:

$\mathrm{Y}=$ Variabel dependen (nilai yang diprediksikan)

$\mathrm{X}=$ Variabel Independen

$\mathrm{a}=$ Konstanta (nilai $\mathrm{Y}$ apabila $\mathrm{X}=0$ )

$\mathrm{b}=$ Koefisien regresi (nilai peningkatan atau penurunan).

Untuk mencari nilai a dapat menggunakan rumus:

$$
a=\frac{\left(\sum Y\right)\left(\sum X^{2}\right)-\left(\sum X\right)\left(\sum X Y\right)}{n\left(\sum X^{2}\right)-\left(\sum X\right)^{2}}
$$

(Sugiyono, 2015: 188)

Sedangkan untuk mencari nilai b dapat menggunakan rumus :

2. Analisis Koefisi korelasi

$$
=\frac{n\left(\sum X Y\right)-\left(\sum X\right)(\Sigma Y)}{n\left(\sum X^{2}\right)-\left(\sum X\right)^{2}}
$$

Sumber: Sugiyono (Sugiyono, 2015: 188)

Koefisien korelasi sederhana menunjukan seberapa besar hubungan yang terjadi antara dua variabel. Untuk menghitung Analisis Koefisien Korelasi, maka dalam penelitian ini akan digunakan rumus Koefisien Korelasi Product Moment sebagai berikut:

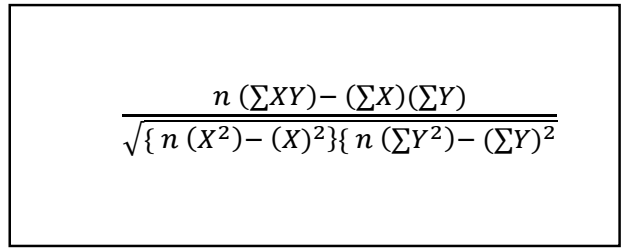

(Sugiyono 2015: 286)

Keterangan:

$r_{x y}=$ Koefisien Korelasi Product Moment antara X dan Y

$\mathrm{X}=$ Variabel Independen

$\mathrm{Y}=$ Variabel Dependen

$\mathrm{n}=$ Jumlah Responden

Untuk mengetahui tingkat hubungan koefisien korelasi dapat digunakan tabel sebagai berikut:

Tabel 1.1

Pedoman Untuk Memberikan Interprestasi Koefisien Korelasi

\begin{tabular}{cc}
\hline $\begin{array}{c}\text { Interval } \\
\text { Koefisien }\end{array}$ & $\begin{array}{c}\text { Tingkat } \\
\text { Hubungan }\end{array}$ \\
\hline $\mathbf{0 , 0 0 0 - 0 , 1 9 9}$ & Sangat Lemah \\
\hline $\mathbf{0 , 2 0 0 - \mathbf { 0 , 3 9 9 }}$ & Lemah \\
\hline $\mathbf{0 , 4 0 0 - 0 , 5 9 9}$ & Sedang \\
\hline $\mathbf{0 , 6 0 0 - 0 , 7 9 9}$ & Kuat \\
\hline $\mathbf{0 , 8 0 0 - 1 , 0 0 0}$ & Sangat Kuat \\
\hline
\end{tabular}

(Sugiyono, 2015: 287)

\section{Koefisien Determinasi (KD)}

Menurut Sugiyono (Sugiyono 2015:185) menyatakan bahwa: "Analisis korelasi dapat dilanjutkan dengan menghitung koefisien determinasi, dengan cara mengkuadratkan koefisien yang ditemukan".

Adapun rumus koefisien determinasi adalah sebagai berikut:

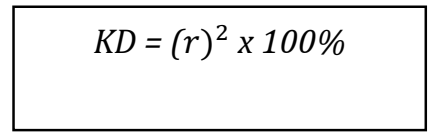

(Sugiyono, 2015:185)

Keterangan:

$\mathrm{KD}=$ Nilai Koefisien determinasi

$\mathrm{r}=$ Nilai koefisien korelasi product moment 
Uji Hipotesis (Uji Signifikansi atau Uji t)

Menurut sunyoto (2013:50), bahwa: "Uji signifikan atau uji t digunakan untuk menguji apakah suatu variabel bebas berpengaruh atau tidak terhadap variabel terikat". Adapun rumus uji signifikan atau uji t sebagai berikut:

$$
t_{\text {hitung }}=\frac{r \sqrt{n-2}}{\sqrt{1-r^{2}}}
$$

(Sugiyono, 2013: 50)

Keterangan:

$\mathrm{t}=$ nilai $\mathrm{t}$ hitung

$\mathrm{r}=$ nilai koefisien korelasi

$\mathrm{n}=$ lama tahun

\section{HASIL DAN PEMBAHASAN}

\section{Peran Ayah dan Ibu dalam Keluarga}

Untuk mencapai interaksi yang baik antara ayah dan ibu dengan anak- anaknya, maka dalam keluarga itu harus menjalankan peranannya sesuai dengan fungsi dan kedudukannya, baik di dalam keluarga itu sendiri maupun di lingkungan masyarakat. Berikut ini penulis akan menguraikan peranan-peranan tersebut:

\section{Peran Ayah}

Peran ayah adalah sebagai pemegang peranan penting disamping mempunyai kewajiban sebagai tulang punggung dengan berprofesi sebagai petani, ia juga merupakan seseorang yang bertanggungjawab dalam perkembangan anak-anaknya, baik secara fisik maupun secara psikis. Dengan demikian, selain memenuhi kebutuhan secara fisik seperti makan, minum, sandang dan sebagainya, ayah juga aktif membina perkembangan pendidikan anak. ${ }^{9}$

Anak memandang ayahnya sebagai orang tertinggi prestasinya, yang berarti ayah merupakan pemimpin yang patut dijadikan

\footnotetext{
9 Aly, Hary Hoer.Imu Pendidikan Islam. (Jakarta: Lobos Wacana Ilmu,1999), hlm.2

10 Aly, Hary Hoer.Imu Pendidikan Islam. (Jakarta: Lobos
} Wacana Ilmu,1999), hlm.3 cermin bagi anaknya atau dengan kata lain ayah merupakan tauladan yang terpandai dan berwibawa. Dengan demikian, setiap perilaku ayah merupakan contoh dorongan bagi anak untuk mengikutinya. ${ }^{10}$

\section{Peranan Ibu}

Peranan seorang ibu bagi anakanaknya sangat besar, karena anak- anak lebih dekat hubungannya kepada ibu daripada kepada ayahnya dalam kehidupan sehari-hari. Oleh karena itu, seorang ibu harus benar- benar berfungsi dalam menunaikan tugasnya, antara lain dalam pemeliharaan pendidikan anak-anaknya agar mereka menjadi anak yang berguna dan menjadi anak yang shaleh. ${ }^{11}$

Pembinaan pendidikan seorang ibu terhadap anaknya merupakan pendidikan dasar yang tidak dapat diabaikan sama sekali. Maka dari itu, seorang ibu hendaknya bijaksana dan pandai mendidik anakanaknya. Nyatalah betapa berat tugas seorang ibu sebagai pendidik dan pengatur rumah tangga. Baik buruknya pendidikan seorang ibu terhadap anaknya akan berpengaruh besar terhadap perkembangan dan watak anaknya dikemudian hari, karena ibu adalah seseorang yang pertama berkomunikasi langsung dengan anaknya.

Pernyataan rasa kasih sayang dan perlindungan merupakan hal sangat penting bagi anak untuk mengembangkan rasa percaya diri dan terhindar dari rasa takut serta gelisah yang akan mengganggu perkembangan jiwa anak. Peranan ibu dalam pendidikan anak-anaknya adalah sumber dan pemberi rasa kasih sayang, pengasuh dan pemelihara, tempat mencurahkan isi hati, pengatur kehidupan dalam rumah tangga, serta pendidik dalam segi-segi emosional. ${ }^{12}$

\section{Macam-macam Perhatian}

Untuk mempermudah memahami bentuk perhatian dalam kehidupan sehari-

\footnotetext{
${ }^{11}$ Aly, Hary Hoer.Ilmu Pendidikan Islam. (Jakarta: Lobos Wacana Ilmu,1999), hlm.4

12 Aly, Hary Hoer.Ilmu Pendidikan Islam. (Jakarta: Lobos Wacana Ilmu,1999), hlm.5
} 
hari, maka perlu pengelompokan. Ditinjau dari berbagai hal, perhatian dapat dikelompokan dan dibedakan menjadi beberapa macam sebagai berikut: Atas dasar intensitasnya, yaitu banyak sedikitnya kesadaran yang menyertai sesuatu aktivitas atau pengalaman batin.

Atas dasar luasnya objek, perhatian ini menurut Suryabrata terbagi menjadi dua yaitu: Perhatian yang sempit, yaitu perhatian individu terhadap sesuatu objek yang sedikit. Orang yang memiliki perhatian sempit dapat dengan mudah memusatkan perhatiannya kepada suatu objek yang terbatas, sekalipun orang tersebut berada dalam situasi keramaian. Orang semacam ini tidak mudah memindahkan perhatiannya kepada objek lain, jiwanya tidak mudah tergoda oleh keadaan sekelilingnya.

Perhatian yang luas, yaitu perhatian individu yang pada suatu saat dapat memusatkan perhatiannya kepada suatu objek yang banyak secara bersamaan. Orang yang mempunyai perhatian luas mudah sekali tertarik oleh kejadian-kejadian sekelilingnya dan perhatiannya tidak dapat mengarah pada hal-hal tertentu.

\section{Faktor-faktor yang Mempengaruhi Perhatian}

Sebuah perhatian tidak timbul begitu saja pada diri seseorang. Di bawah ini akan diuraikan beberapa faktor yang mempengaruhi perhatian menurut Ahmadi sebagai berikut: Adanya pembawaan tertentu yang berhubungan dengan objek yang direaksi, maka sedikit atau banyak akan timbul perhatian terhadap objek tertentu. ${ }^{13}$

Latihan dan Kebiasaan. Meskipun dirasa tidak ada bakat pembawaan tentang suatu bidang, tetapi karena hasil latihan dan kebiasaan, maka dapat memudahkan timbulnya perhatian terhadap bidang tersebut. Kebutuhan. Adanya kebutuhan tentang sesuatu memungkinkan timbulnya perhatian terhadap objek tersebut. Kebutuhan merupakan dorongan,

13 Ahmadi, Abu. Ilmu Pendidikan. Jakarta: PT. Rineka Cipta, 2003), hlm,150 sedangkan dorongan itu mempunyai tujuan yang harus dicurahkan kepadanya. Kewajiban. Kewajiban mengandung tanggungjawab yang harus dipenuhi oleh orang yang bersangkutan. Bagi orang yang bersangkutan dan menyadari atas kewajibannya, maka orang tersebut tidak akan bersikap masa bodoh dalam melaksanakan tugasnya.

\section{Bentuk-bentuk Perhatian Orangtua}

Orangtua dalam memberikan perhatian tidaklah harus dengan sesuatu yang mahal atau bahkan sesuatu yang berlebihan. Perhatian dapat ditunjukan dengan hal-hal kecil yang dimulai dengan kebiasaan dalam keluarga. Bentuk perhatian orangtua tidaklah terbatas pada satu perilaku atau tindakan. Kebutuhan yang bersifat psikis dan non psikis meliputi perhatian, rasa kasih sayang, rasa nyaman, motivasi, keadilan, religi, dan sebagainya. Hal tersebut dapat diwujudkan dengan cara sebagai berikut:

1. Membudayakan sikap terbuka dan saling mengingatkan;

2. Membangun komunikasi jelas dan lancar antara orangtua dengan anak;

3. Menciptakan suasana yang akrab dan nyaman untuk sekedar berbincangbincang;

4. Mendukung dan memotivasi kegiatan anak yang bersifat positif; Memberikan surprise atau kejutankejutan dan hadiah pada anak atas prestasi yang diraih;

5. Berkreasi di akhir pekan bersama keluarga;

6. Melakukan ibadah bersama dan menanamkan nilai religi pada anak sejak dini; dan

7. Mendampingi anak saat belajar. ${ }^{14}$

\section{Konsep Prestasi Belajar}

Menurut Kamus Besar Bahasa Indonesia prestasi adalah: "Penguasaan pengetahuan atau keterampilan yang

\footnotetext{
14 Ahmadi, Abu dan Widodo Supriyono. Psikologi Belajar. (Jakarta: Rineka Cipta, 2004). hlm, 90
} 
dikembangkan kemudian ditunjukkan dengan nilai tes atau angka yang diberikan oleh pengajar". Prestasi belajar merupakan cerminan dari tingkatan yang mampu dicapai oleh siswa atau mahasiswa dalam meraih tujuan yang sudah dicapai.

Prestasi adalah hasil yang telah dicapai seseorang dalam melakukan kegiatan. Gagne menyatakan bahwa prestasi belajar dibedakan menjadi 5 aspek, yaitu: kemampuan intelektual, strategi kognitif, informasi verbal, sikap dan keterampilan. ${ }^{15}$

Menurut Aunurrahman dalam sebuah buku The Guidance of Learning Activities, merumuskan pengertian belajar sebagai perubahan tingkah laku pada diri individu dengan lingkungannya, sehingga mereka mampu berinteraksi dengan lingkungannya. Dalam buku Educational Psychology, H.C. Witherington mengemukakan bahwa belajar adalah suatu perbuatan di dalam kepribadian yang menyatakan diri sebagai suatu pola baru dari reaksi berupa kecakapan, sikap, kebiasaan, kepribadian, atau suatu pengertian. Dalam sebuah situs tentang pengertian belajar. ${ }^{16}$

Dalam kesimpulan yang dikemukakan Abdillah, belajar adalah suatu usaha sadar yang dilakukan oleh individu dalam perubahan tingkah laku, baik melalui latihan dan pengalaman yang menyangkut aspek kognitif, afektif, dan psikomotorik untuk memperoleh tujuan tertentu. ${ }^{17}$

Prestasi belajar adalah hasil yang dicapai seseorang dalam penguasaan pengetahuan dan keterampilan yang dikembangkan dalam pelajaran, lazimnya ditunjukkan dengan tes angka atau nilai yang diberikan oleh guru, prestasi belajar merupakan bukti keberhasilan yang telah dicapai oleh seseorang. ${ }^{18}$

Perhatian ayah dan ibu berpengaruh terhadap berbagai pertumbuhan dan perkembangan seseorang. Setiap orang yang selalu mendapatkan perhatian akan

\footnotetext{
15 Gagne, R. The Conditions of Learning. (New York: Holt, Rinehart \& Winston, 1985), hlm, 40

16 Aunurrahman.Belajar dan Pembelajaran. (Bandung: CV Alfabeta, 2012), hlm, 35

17 Abdillah. Pengertian Belajar dari Berbagai Sumber (Belajar dan
}

memperoleh prestasi belajar yang berbeda dengan seseorang yang tidak pernah mendapatkan perhatian dari orangtua mereka. Hal ini sangat erat hubungannya dengan prestasi belajar siswa SMK Negeri 1 Rajadesa Kabupaten Ciamis.

Hasil dari penelitian yang telah dilakukan dengan jumlah responden 63 orang diperoleh dalam deskriptif statistik perhatian orangtua dengan rata-rata (mean) adalah 25,52, skor tertinggi adalah 27,00, skor minimalnya adalah 23,00 , perbedaan antara nilai tertinggi dan terendah (range) adalah 24,05, dan standar deviasi dari kumpulan data yang telah disusun adalah 4,00 serta data-data yang lainnya. Nilai ratarata untuk perhatian orangtua adalah 25,52. Dengan rata-rata sebesar 25,52 karena berada pada rentang nilai antara 24,00-25.00, maka dapat disimpulkan bahwa rata-rata variabel X yaitu perhatian orang tua terhadap mata pelajaran pendidikan agama Islam di SMK Negeri 1 Rajadesa Kecamatan Rajadesa Kabupaten Ciamis adalah lemah.

Sedangkan untuk prestasi belajar siswa diperoleh dalam deskriptif statistik dengan nilai rata-rata (mean) adalah 24,63, skor tertinggi untuk variabel $\mathrm{Y}$ adalah 34,00, skor minimalnya adalah 22,00, perbedaan antara nilai tertinggi dan terendah (range) adalah 23,00, dan standar deviasi dari kumpulan data yang telah disusun adalah 3,539 serta data- data yang lainnya.

Hal ini menunjukan bahwa perhatian orang tua termasuk pada kategori sangat lemah, karena berada pada rentang 22-34. Selain itu, hasil uji normalitas dengan menggunakan Test of Normality Kolmogorov Smirnov diperoleh dengan nilai 0,861 yang artinya $0,861<0,05$, maka dapat disimpulkan bahwa variabel $\mathrm{X}$ (perhatian orangtua) dalam penelitian ini berdistribusi lemah.

Sedangkan perolehan uji normalitas data variabel $\mathrm{Y}$ dengan signifikansi 0,071

Pembelajaran). (Bandung: CV Alfabeta, 2002), hlm84

18 Asmara. Prestasi Belajar. (Bandung: PT. Remaja

Rosdakarya, 2009). hlm,11 
yang artinya $0,071<0,05$, maka dapat disimpulkan bahwa variabel $\mathrm{X}$ (perhatian orangtua) dalam penelitian ini berdistribusi lemah.

Hasil uji linieritas anatar variabel $\mathrm{X}$ dan variabel $\mathrm{Y}$ diperoleh dengan nilai signifikansi 0,615 lebih kecil dari 0,05 yang artinya terdapat hubungan linier secara signifikan antara variabel $\mathrm{X}$ (perhatian orangtua pada mata pelajaran pendidikan agama Islam di SMK Negeri 1 Rajadesa Kabupaten Ciamis) dan variabel Y (prestasi belajar siswa pada mata pelajaran pendidikan agama Islam di SMK Negeri 1 Rajadesa Kecamatan Rajadesa Kabupaten Ciamis).

Selain itu, hasil dari uji koefisien korelasi signifikansi 0,105 berada pada rentang $0,20-0,00$, maka pengaruh variabel $\mathrm{X}$ (perhatian orangtua pada mata pelajaran pendidikan agama Islam di SMK Negeri 1 Rajadesa Kecamatan Rajadesa Kabupaten Ciamis) terhadap variabel Y (prestasi belajar siswa pada mata pelajaran pendidikan agama Islam di SMK Negeri 1 Rajadesa Kecamatan Rajadesa Kabupaten Ciamis) merupakan korelasi sangat lemah.

\section{KESIMPULAN}

Berdasarkan pembahasan dan hasil penelitian yang penulis lakukan, maka kesimpulan dari hubungan perhatian orangtua dan prestasi belajar siswa pada mata pelajaran Pendidikan Agama Islam di SMK Negeri 1 Rajadesa Kecamatan Rajadesa Kabupaten Ciamis adalah sebagai berikut: Perhatian orangtua siswa di SMK Negeri 1 Rajadesa Kecamatan Rajadesa dengan ratarata (mean) adalah 25,52, skor tertinggi adalah 27,00 , skor minimalnya adalah 23,00 , perbedaan antara nilai tertinggi dan terendah (range) adalah 4,00, dan standar deviasi dari kumpulan data yang telah disusun adalah 4,457 serta data-data yang lainnya. Nilai ratarata untuk perhatian orangtua adalah 25,52 . Dengan rata-rata sebesar 25,52 karena berada pada rentang nilai antara 24,00-25,00, maka dapat disimpulkan bahwa rata-rata variabel X yaitu perhatian orang tua terhadap mata pelajaran pendidikan agama Islam di SMK Negeri 1 Rajadesa Kecamatan Rajadesa Kabupaten Ciamis adalah lemah.

Prestasi belajar siswa pada mata pelajaran Pendidikan Agama Islam di SMK Negeri 1 Rajadesa Kecamatan Rajadesa Kabupaten Ciamis sebesar 25,62: $94 \times 100=$ 2,68. Dengan rata-rata sebesar 25,03 karena berada pada rentang nilai antara 20-100, maka dapat disimpulkan bahwa rata-rata variabel X yaitu perhatian orangtua terhadap mata pelajaran pendidikan agama Islam di SMK Negeri 1 Rajadesa Kecamatan Rajadesa Kabupaten Ciamis adalah sangat lemah.

\section{DAFTAR PUSTAKA}

Abdillah. (2002). Pengertian Belajar dari Berbagai Sumber Belajar dan Pembelajaran). Bandung: CV Alfabeta.

Ahmadi, Abu. (2004). Ilmu Pendidikan. Jakarta: PT. Rineka Cipta.

Ahmadi, Abu \& Widodo Supriyono. (2004). Psikologi Belajar. Jakarta: Rineka Cipta.

Aly, Hary Hoer. (1999). Ilmu Pendidikan Islam. Jakarta: Lobos Wacana Ilmu.

Arikunto, Suharsimi. (2011). Dasar-Dasar Evaluasi Pendidikan. Jakarta: Bumi Aksara.

Asmara. (2011). Prestasi Belajar. Bandung: PT. Remaja Rosdakarya.

Aunurrahman. (2012). Belajar dan Pembelajaran. (Bandung: CV Alfabeta.

Djamarah, Syaiful Bahri. (2018). Psikologi Belajar. Jakarta: Rineka Cipta.

Gagne, R. (1985). The Conditions of Learning. New York: Holt, Rinehart \& Winston.

Gunarsa, Ny Singgih. (2014). Psikologi untuk Keluarga. Jakarta: Gunung Mulia.

Harjati. (2018). Psikologi Belajar. Jakarta: PT. Rineka Cipta.

Kartono, Kartini. (2015). Peranan Keluarga Memandu Anak, Sari Psikologi Terapan. Jakarta: Rajawali Press.

Nazir, Moh. (2011). Metode Penelitian. Bogor: Ghalia Indonesia. 
Dudi Badruzaman / Ta'dib: Jurnal Pendidikan Islam, Vol. 8 No. 1 (2019) 591-600 ISSN 1411-8173 | E-ISSN 2528-5092

https://ejournal.unisba.ac.id/index.php/tadib/article/view/5063

Priyanto. (2018). Farmakologi Dasar. Jakarta:

Leskonfi. 